\title{
Is Na-butyrate a growth factor in the preruminant calf? Preliminary results
}

\author{
P. Guilloteau ${ }^{1,3}$, V. Romé ${ }^{1}$, L. Le Normand ${ }^{1}$, G. Savary ${ }^{1}$ \\ and R. Zabielski ${ }^{2}$ \\ ${ }^{I}$ INRA-UMRVP, Domaine de la Prise \\ 35590 Saint Gilles, France \\ ${ }^{2}$ Department of Physiological Sciences, Faculty of Veterinary Medicine, \\ Warsaw Agriculture University \\ Nowoursynowska 159, 02-776 Warsaw, Poland
}

\begin{abstract}
Na-butyrate was studied as a candidate food additive in artificial milk replacer, which may potentially replace the use of feed antibiotics in the preruminant calf. The results of two experiments employing Na-butyrate are shown. Supplementation of milk replacer with Na-butyrate increased pancreatic exocrine secretion, probably due to stimulation of secretagogue gut regulatory peptides, which in turn resulted in better digestion efficiency and enhanced animal's growth. The carcass weight was also increased. Finally, Na-butyrate may be a good candidate to replace antibiotics as growth promotors in artificial milk replacers but more studies are necessary to explain the mechanisms involved.
\end{abstract}

KEY WORDS: Na-butyrate, preruminant calf, growth, digestibility, pancreatic secretion, gut regulatory peptides

\section{INTRODUCTION}

The Na-butyrate molecule is a sodium salt of butyric acid, one of the shortchain fatty acid (SCFA) family. Butyric acid is a main end product of anaerobic bacterial fermentation of carbohydrates in the rumen of ruminant species and in the colon of omnivorous species including humans. Now, a lot of attention is paid to its anticancerous properties in human nutrition, much more in comparison with its growth inducing effects in the gastrointestinal mucosa (Pouillart, 1998). Nevertheless, several studies have shown its important role in growth stimulation,

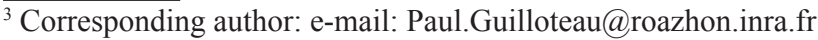


and Na-butyrate is often used instead of butyric acid, since it is solid, stabile and much less odorous. Na-butyrate increased the protein synthesis (Kruh, 1982) and reduced apoptosis in the bovine rumen (Mentschel et al., 2001), and in the large intestine in pig and guinea pig (Hass et al., 1997). Butyrate supplementation increased the villi lenght, crypt depth and the mitotic index in the gut (Galfi and Bokori, 1990; Kotunia et al., 2004).

In the in vitro studies with pancreatic lobuli preparations, Na-butyrate administration resulted in enhanced amylase release in the goat and sheep preparations (Harada and Kato, 1983). Intravenous injection (in anaesthetized pigs and calves or in conscious guinea pigs) and intra-duodenal perfusion (in rats) of Na-butyrate stimulated pancreatic secretion (Demol and Sarles, 1978; Harada and Kato, 1983; Kato et al., 1989; Katoh and Yajima, 1989). Feeding a diet enriched in butyrate, resulted in increased enzyme activities in the small intestinal mucosa (Galfi et al., 1993). Moreover, in rats, Na-butyrate infusion into the lumen of the large intestine stimulated the mucin secretion (Barcelo et al., 2000). Finally, it was shown that Na-Butyrate is implicated in gene expression (Tsubaki et al., 2001; Böker et al., 2003).

From these reports, we hypothesized that Na-butyrate could act like a growth factor in the gastrointestinal tract. In the present studies, we assessed the effects of Na-butyrate used as an additive in the diet on growth performance, digestibility of nutrients and pancreatic secretion in the preruminant calf.

\section{MATERIAL AND METHODS}

Two experiments were performed. In experiment 1, 44 preruminant calves were divided in 2 groups from $8 \mathrm{~d}$ of age until slaughter at $\mathrm{d} 145$. The two groups successively received three diets: from d 8 to $\mathrm{d} 43$ a "start diet" without skim milk powder (SMP) $(4,000 \mathrm{kcal} / \mathrm{kg}, 20.5,18,0$ and $7.50 \%$ for nitrogenous matters, fats and minerals, respectively, on a dry matter (DM) basis), from d 44 to $\mathrm{d} 50$ a "growth diet" (5.000 kcal, 21.5, 20.5 and 6.0\% are the corresponding values) and finally, from d 51 until slaughter, a mixture of the "growth diet" and another diet without SMP (4.320 kcal, 8.0, 13.5 and $6.0 \%$ are the corresponding values). During the whole experiment, the first group was used as control group (C group) and fed the 3 milk replacers supplemented with flavomycin, whereas the second group (B group) was used as treatment group and fed the same 3 milk replacers but with Na-butyrate (3\% on DM basis) instead of flavomycin. A standard feeding schedule was applied for both groups and the calves were fed twice daily at 08.30 and $16.30 \mathrm{~h}$.

In experiment 2, four calves older than $30 \mathrm{~d}$ were used, since the digestive processes develop intensely during the first month of life. The calves were fitted with two permanent catheters inserted into the accessory pancreatic duct and 
duodenum under halothane anaesthesia (Le Dréan et al., 1997). The animals were fed a milk replacer based on SMP and tallow ( $240 \mathrm{~g}$ crude protein, $200 \mathrm{~g}$ fat, $447 \mathrm{~g}$ lactose, $39 \mathrm{~g}$ starch, and $74 \mathrm{~g}$ ash per $\mathrm{kg} \mathrm{DM}$ ). They were fed twice daily at 08.30 and $16.30 \mathrm{~h}$. The DM intake was $66 \mathrm{~g}$ per $\mathrm{kg}$ metabolic body weight $\left(\mathrm{BW}^{0.75}\right)$. The calves received the milk replacer containing bacitracin as an antibacterial growth promoter. Calves were placed in metabolic crates to measure nutrient digestibility during a 4-d period before the surgery ( $\mathrm{P} 0)$, and after their recovery during the 3 consecutive 4-d periods ( $\mathrm{P} 1$ with milk replacer alone; C-diet), then P2 and P3 with the milk replacer supplemented with Na-butyrate (3\% on DM basis; B-diet). The pure pancreatic juice was collected during each period after the surgery, measured for volume, and $92 \%$ of the secretion was continuously re-infused into the duodenum. The remaining $8 \%$ was pooled to have a representative sample of the juice secreted during the whole day, and it was analysed for total protein and trypsin (Le Dréan et al., 1997).

\section{RESULTS AND DISCUSSION}

In the two experiments, the calves had no health problems. The refused quantities of feed were low and there was no difference between the 2 diets. During the entire experiment 1, total DM intake was similar for both groups $(256.5 \mathrm{~kg})$. The BW gain was the same in the $\mathrm{C}$ and $\mathrm{B}$ groups until $35 \mathrm{~d}$ of age. From d 35 and until slaughter, BW gain was higher in $\mathrm{B}$ than in $\mathrm{C}$ group $(\mathrm{P}<0.05)$, and feed efficiency was improved (1.82 vs $1.72 \mathrm{~kg} \mathrm{BW}$ gain $/ \mathrm{kg} \mathrm{DM} ; \mathrm{P}<0.05)$. Thus, BW measured at the end of the study was 195.1 and $200.5 \mathrm{~kg}$ in the $\mathrm{C}$ and $\mathrm{B}$ group $(\mathrm{P}<0.05)$, respectively. At slaughter, the carcass weight was $5.2 \mathrm{~kg}$ higher in the $\mathrm{B}$ group compared to the $\mathrm{C}$ group $(\mathrm{P}<0.05)$. Thus, animal performance was improved when antibiotic was replaced by Na-butyrate.

In experiment 2, the apparent faecal nutrient digestibility was not modified by surgery for all the nutrients studied, but it was largely improved for the B-diet in comparison to the $\mathrm{C}$-diet. For the $\mathrm{B}$ - and $\mathrm{C}$-diet the values were: 0.929 vs 0.915 $(\mathrm{P}<0.05)$ for $\mathrm{DM}$ and 0.868 vs $0.840(\mathrm{P}=0.07)$ for nitrogen, respectively. In the same way, pancreatic secretions were increased with the B-diet by $25.5 \%$ for juice volume (10.8 vs $8.6 \mathrm{~g} / \mathrm{kg} \mathrm{BW} ; \mathrm{P}=0.15)$ and by $38 \%$ for trypsin activity (106 vs 77 $\mathrm{IU} / \mathrm{d} / \mathrm{kg} \mathrm{BW} ; \mathrm{P}<0.05)$. The later results correspond with an increase in circulating plasma gastrin and cholecystokinin (data not shown), and could explain, at least in part, the improvement of digestibility as it was reported by Guilloteau et al. (1999) and Guilloteau and Zabielski (2004). The enhanced digestibility seen in the "laboratory" experiment 2 can be explained by increased secretion of pancreatic juice. Taken together the results help to explain the beneficial results obtained in the "field" experiment 1. 


\section{CONCLUSIONS}

In the present experiments with calves, administration of Na-butyrate as a feed additive in the diet seems to act as a growth promoter in preruminant calves by increasing the efficacy of digestion. Finally, it is suggested that Na-butyrate can be a good candidate molecule to replace antibiotics as growth promoters in milk replacers. More studies are necessary to explain the mechanisms involved.

\section{REFERENCES}

Barcelo A., Claustre J., Moro F., Chayvialle J.A., Cuber J.C., Plaisancié P., 2000. Mucin secretion is modulated by luminal factors in the isolated vascularly perfused rat colon. Gut 66, 218-224

Böcker U., Nebe T., Herweck F., Holt L., Panjas A., Jobin C., Rossol S., Sartor R.B., Singer M.V., 2003. Butyrate modulates intestinal epithelial cell-mediated neutrophil migration. Clin. Exp. Immunol. 131, 53-60

Demol P., Sarles H., 1978. Action of fatty acids on the exocrine pancreatic secretion of the conscious rat: further evidence for a protein pancreatic inhibitory factor. J. Physiol. 275, 27-37

Galfi P., Bokori J., 1990. Feeding trial in pigs with a diet containing sodium n-butyrate. Acta Vet. Hung. 38, 3-17

Galfi P., Gabel G., Martens H., 1993. Influences of extracellular matrix components on the growth and differentiation of ruminal epithelial cells in primary culture. Res. Vet. Sci. 54, 102-109

Guilloteau P., Le Huërou-Luron I., Romé V., Plodari M., 1999. Nutrient absorption is related to quantity of pancreatic enzyme secretion. S. Afr. J. Anim. Sci. 29, 241-242

Guilloteau P., Zabielski R., 2004. Digestive secretions in preruminant and ruminant calves and some aspects of their regulation. In: P. Garnsworthy (Editor). Rearing the Modern Dairy Heifer. Nottingham, University Press (in press)

Harada E., Kato S., 1983. Effect of short-chain fatty acids on the secretory response of the ovine exocrine pancreas. Amer. J. Physiol. - Gastrointest. L. 7, G284-G290

Hass R., Bushe R., Luciano L., Reale E., Engelhardt W.V., 1997. Lack of butyrate is associated with induction of Bax and subsequent apoptosis in the proximal colon of guinea pig. Gastroenterology $112,875-881$

Kato S., Asakawa N., Mineo H., Ushijima J., 1989. Effect of short-chain fatty acids on pancreatic exocrine secretion in calves aged 2 weeks and 13 weeks. Jpn. J. Vet. Sci. 51, 1123-1127

Katoh K., Yajima T., 1989. Effects of butyric acid and analogues on amylase release from pancreas segments of sheep and goats. Pflüger Arch. 413, 256-260

Kotunia A., Woliński J., Laubitz D., Jurkowska M., Rome V., Guilloteau P., Zabielski R., 2004. Effect of sodium butyrate on the small intestine development in neonatal piglets feed by artificial sow. J. Physiol. Pharmacol. 55 (in press)

Kruh J., 1982. Effects of sodium butyrate, a new pharmacological agent, on cells in culture. Mol. Cell. Biochem. 42, 65-82

Le Dréan G., Le Huërou-Luron I., Chayvialle J.A., Philouze-Romé V., Gestin M., Bernard C., Toullec R., Guilloteau P., 1997. Kinetics of pancreatic exocrine secretion and plasma gut regulatory peptide release in response to feeding in preruminant and ruminant calves. Comp. Biochem. Physiol. 117A, 245-255

Mentschel J., Leiser R., Mulling C., Pfarrer C., Claus R., 2001. Butyric acid stimulates rumen mucosa development in the calf mainly by a reduction of apoptosis. Arch. Anim. Nutr. 55, 85-102

Pouillart P.R., 1998. Role of butyric acid and its derivatives in the treatment of colorectal cancer and hemoglobinopathies. Life Sci. 63, 1739-1760

Tsubaki J., Choi W.K., Ingermann A.R., Twigg S.M., Kim H.S., Rosenfeld R.G., Oh Y., 2001. Effects of sodium butyrate on expression of members of the IGF-binding protein superfamily in human mammary epithelial cells. J. Endocrinol. 169, 97-110 